\title{
BATIK LARANGAN DI KERATON YOGYAKARTA PADA MASA PEMERINTAHAN SRI SULTAN HB VII
}

\author{
Anna Galuh Indreswari *)
}

\begin{abstract}
ABSTRACK
Batik cloth which usually contain spiritual values are generally made in the palace or Vorstenlanden, including batik in Yogyakarta Palace(Keraton). The batik of Keraton Yogyakarta aremade with special treatment preferentially both in terms of color application and the use of motifs. Both aspects believed to have spiritual values and a certain symbolic meaning. Batik activity believed to be a ritual of worship and the batik cloth has a religious magical glow when it worn by a person. It becomes important to be studied further, especially associated with the advent of prohibition(Larangan) in the community batik of Yogyakarta Palace in the reign of Sultan HB VII.
\end{abstract}

Research on this batik is qualitative researchand using a multidisciplinary approach. At least two approaches were used namely historical and archaeological approach .

Key words: batik ban (Larangan), motifs, Keraton Yogyakarta, Sultan HB VIII.

\section{ABSTRAK}

Kain batik yang biasanya mengandung nilai spiritual umumnya terdapat dan dibuat di lingkungan Keratonatau vorstenlanden, termasuk batik yang berada di Keraton Yogyakarta. Kain batik di Keraton Yogyakarta dibuat secara istimewa baik dalam hal pemberian warna maupun penggunaan motif-motifnya. Kedua aspek tersebut diyakini mempunyai nilai spiritual dan bermakna simbolik tertentu. Kegiatan membatik dipercayai sebagai suatu ritual ibadah dan memiliki pancaran religius magis pada kain batik yang dipakai oleh seseorang. Hal ini menjadi penting untuk dikaji lebih lanjut, apalagi dikaitkan dengan munculnya batik larangan dalam masyarakat Keraton Yogyakarta pada pemerintahan Sultan HB VII.

Penelitian tentang batik ini temasuk jenis penelitian kualitatif yang dalam proses pelaksanaannya akan menggunakan pendekatan multidisiplin. Paling sedikit ada dua pendekatan yang akan digunakan yakni menggunakan pendekatan sejarah dan arkeologi.

Kata kunci: batik Larangan, motif, Keraton Yogyakarta, Sultan HB VIII.

\footnotetext{
* Anna Galuh Indreswari (anna_galuh@yahoo.com) Staf Pengajar Program Studi Kriya Seni, Jurusan Kriya, Fakultas Seni Rupa, Institut Seni Indonesia Yogyakarta.
} 


\section{PENDAHULUAN}

Timbul Haryono menyatakan batik adalah suatu gambar berpola, motif dan coraknya dibuat menggunakan teknik tutup celup. Batik disebut juga sebuah teknik menghias permukaan tekstil dengan cara menahan warna. Batik berarti seni membuat motif di atas kain dengan bahan perintang warna bernama lilin dan pewarnaannya menggunakan teknik pencelupan.

Batik adalah salah satu kekayaan budaya bangsa Indonesia. J.L.A. Brandes, seorang sarjana Belanda mengatakan bahwa ada sepuluh butir kekayaan budaya yang dimiliki oleh bangsa Indonesia, khususnya masyarakat Jawa. Butir-butir itu adalah wayang, gamelan, tembang, membatik, teknologi logam, sistem mata uang, pelayaran, astronomi, sistem pengairan (irigasi) dan sistem pemerintahan yang teratur.

Batik merupakan salah satu local genius yang menjadi ciri khas suatu budaya masyarakat. Local genius dapat diartikan sebagai keseluruhan ciri-ciri kebudayaan yang dimiliki bersama oleh suatu masyarakat atau bangsa sebagai hasil pengalaman mereka di masa lampau. Pengertian tersebut berarti merujuk pada kemampuan budaya setempat dalam menghadapi kebudayaan asing pada waktu kedua kebudayaan tersebut berhubungan (Timbul Haryono, 2008: 80).

Batik dibedakan menjadi dua yaitu Batik Keraton dan Batik Pesisiran (A. N. Suyanto, 2002: 2). Batik Keraton adalah batik yang tumbuh dan berkembang berdasar filsafat kebudayaan Jawa yang mengacu pada nilai-nilai spiritual dan memandang manusia dalam konteks harmoni, serasi dan seimbang. Batik Keraton dinamakan juga dengan batik Vorstelanden. Batik Vorstelanden dapat diartikan sebagai seni kerajinan batik yang terdapat di daerah kerajaan yang pada jaman penjajahan Belanda disebut Vorstelanden, dan menunjuk pada daerah keraton-sentris di Jawa (Koko Sundari, 2002:1).

Batik Pesisiran adalah semua seni kerajinan batik yang berasal dari luar daerah keraton sentris atau di luar daerah Vorstelanden. Pengertian lain mengenai Batik Pesisiran adalah batik dari luar keraton yang tidak terikat pada patokanpatokan alam pikiran bersifat magis (Biranul Anas, 1997: 53). Hal ini menyebabkan batik-batik pesisiran mempunyai bentuk motif yang lebih dinamis dengan warna yang cerah.

Batik Yogyakarta adalah termasuk batik vorstelanden karena masuk dalam wilayah keraton sentris. Bentuk motifnya bersifat simbolis berlatarkan kebudayaan Hindu Jawa. Warna-warnanya cenderung dominan seperti indigo (biru), sogan, hitam dan putih (Koko Sundari, 2002:1). Motifmotifnya yang bersifat simbolis mengandung makna filosofis di dalamnya. Makna filosofis tersebut ada dalam beberapa jenis batik yang disebut batik larangan. Batik larangan adalah jenis batik yang sarat dengan aturan penggunaan dan nilai sakralnya terutama pada masa pemerintahan Sri Sultan HB VII. 
Batik Larangan di Keraton Yogyakarta Pada Masa Pemerintahan Sri Sultan HB VII.

Pembuatan batik bagi lingkungan keraton adalah suatu hal yang sifatnya spiritual. Motif-motif batik keraton dibuat secara istimewa baik motif maupun warnanya. Lingkungan keraton mempercayai adanya pancaran religius magis dari kain batik yang dipakai. Membatik merupakan suatu ibadah bagi lingkungan keraton. Batik keraton yang dihasilkan menjadi sarat nilai sakral, mempunyai ciri tersendiri, harmonis, bentuknya jelas dan formal dengan tata warna dominan coklat soga dan biru nila (Mari, S. Condronegoro, 2010: 47)

Beberapa motif batik keraton terutama yang mempunyai nilai falsafah tinggi, dinyatakan sebagai motif batik larangan untuk digunakan masyarakat umum. Batik bisa disimpulkan adalah suatu ritual spiritual dan meditasi bagi lingkungan keraton, sehingga motifnya pun bermakna filosofis.

Batik larangan adalah pola batik yang mempunyai makna filosofis tinggi sehingga tidak boleh digunakan oleh semua orang. Pepin Van Roojen menyatakan sebagai berikut.

Pola terlarang adalah suatu pola yang diturunkan dari generasi ke generasi berikutnya, penerus keturunan Mataram. Warisan budaya yang dibuat dengan standar pengerjaan yang tinggi dan dianggap sebagai suatu motif batik yang adiluhung (Pepin Van Roojen, 1996: 41).

Beberapa arsip keraton menunjukkan bahwa pada tahun 1792 dan 1798 ada pembatasan terhadap pemakaian batik bercorak semen dengan sawat, lar, cemukiran, dan udan liris. Pada masa pemerintahan Sri Sultan HB VII, pola batik larangan lebih ditekankan pada motif huk dan kawung (Mari, S. Condronegoro: 2010: 49). Kedua motif ini lebih ditekankan larangannya karena mengandung makna filosofis kepemimpinan. Motif larangan selain dua motif itu adalah semen, udan liris, sawat, parang dan cemukiran (Mari, S. Condronegoro, 2010: 54).

\section{Makna Filosofis Batik Larangan di Keraton Yogyakarta.}

Batik Larangan yang mengandung makna filosofis di Keraton Yogyakarta pada masa pemerintahan Sri Sultan HB VII adalah motif huk. Motif huk tergolong motif non geometris yang terdiri dari motif kerang, binatang, tumbuhan, cakra, burung, sawat dan garuda. Kerang melambangkan dunia air yang berarti bermakna lapang hati. Cakra adalah senjata Dewa Wisnu simbol pemelihara dunia. Bentuk binatang menggambarkan watak sentosa, dan tumbuhan bermakna lambang kemakmuran. Motif sawat merupakan ungkapan ketabahan hati (Mari, S. Condronegoro, 2010: 51). Menurut paham islam, burung huk adalah burung peksi atau garuda, kendaraan Nabi Muhammad yang melesat secepat kilat. Motif huk dapat diartikan juga simbol budi luhur dan kepemimpinan yang berpikir cepat dan jernih (Nasution H. Harun, 1992: 182). 


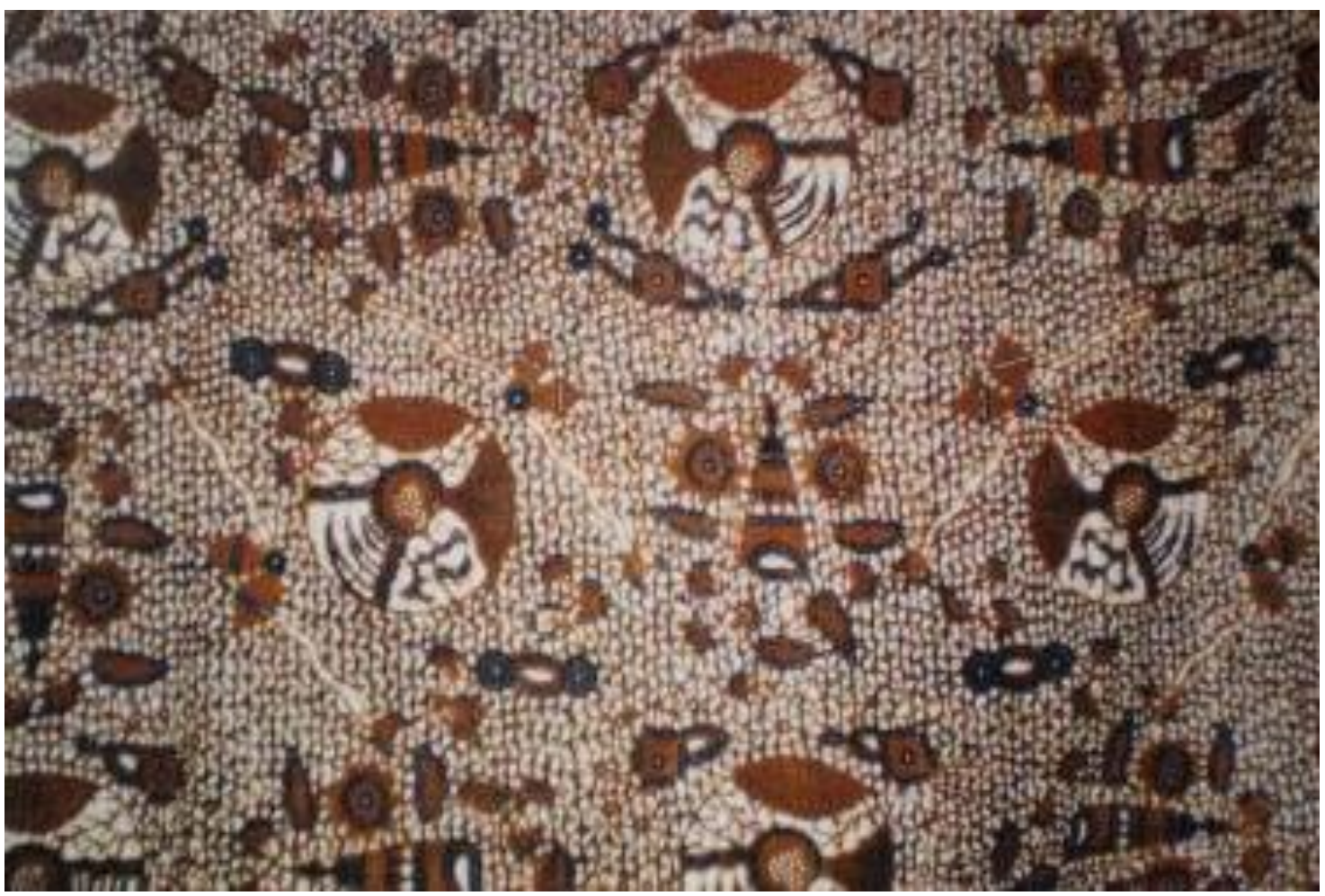

Gbr. 1. Motif Huk, salah satu motif larangan.

Kawung adalah ragam hias tertua yang dikenakan oleh kalangan terbatas. Keempat bulatan pada kawung merupakan empat bentuk yang mengelilingi pusat, yang dalam budaya jawa dikenal dengan istilah keblat papat lima pancer. Hal ini dapat dijabarkan menjadi empat kekuatan tenaga alam atau empat penjuru angin. Timur arah matahari berarti simbol sumber energi. Selatan arat terik matahari merupakan simbol puncak atau zenith. Barat arah matahari terbenam adalah simbol ketenangan dan kematangan. Utara adalah arah kematian, saatnya manusia kembali pada Tuhan (Iwan Tirta, 1985). Konsep ini disebut mancapat.

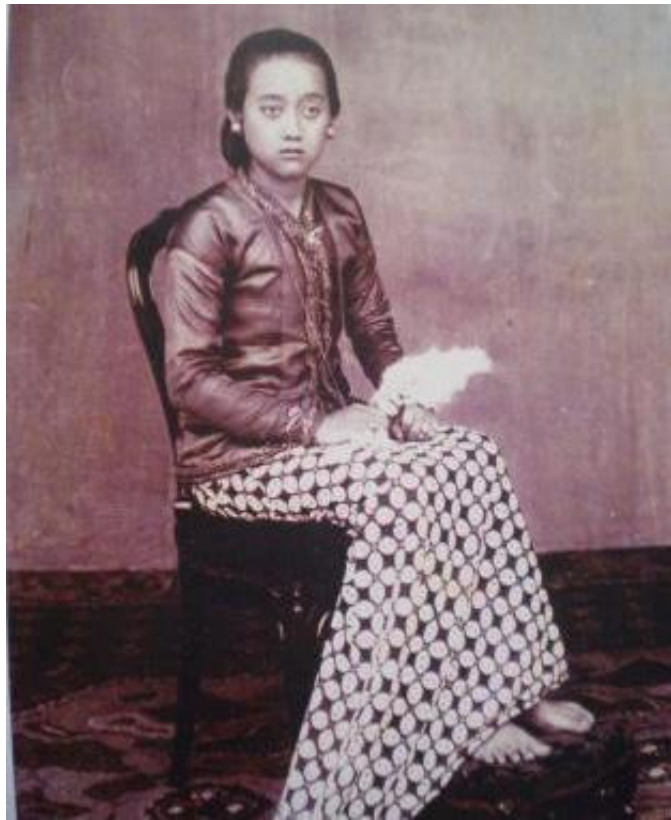

Gbr. 2. Motif batik Kawung dikenakan oleh BRAY Siti Mustokirun (Putri HB VIII). 


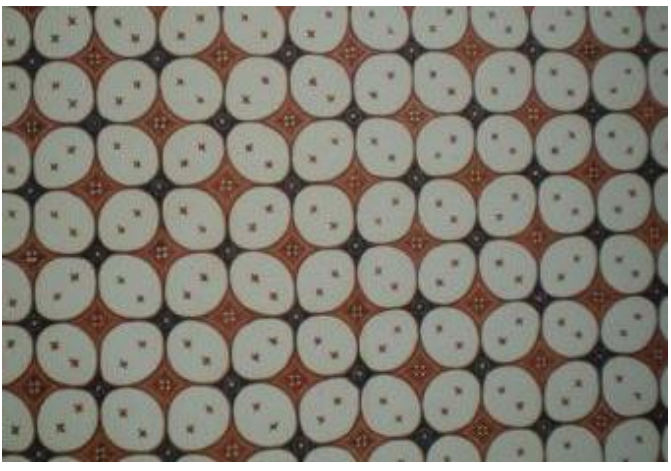

Gbr. 3. Motif batik larangan kawung.

Semen merupakan motif batik yang mengutamakan bentuk tumbuhan dengan akar dan sulurnya. Kata semen mempunyai konotasi semi atau tumbuh sebagai lambang kesuburan, kemakmuran dan alam semesta. Lukisan tanaman pada batik semen diibaratkan pohon kehidupan atau sering juga diartikan sebagai pohon hayat, atau dapat diartikan benih-benih kehidupan.

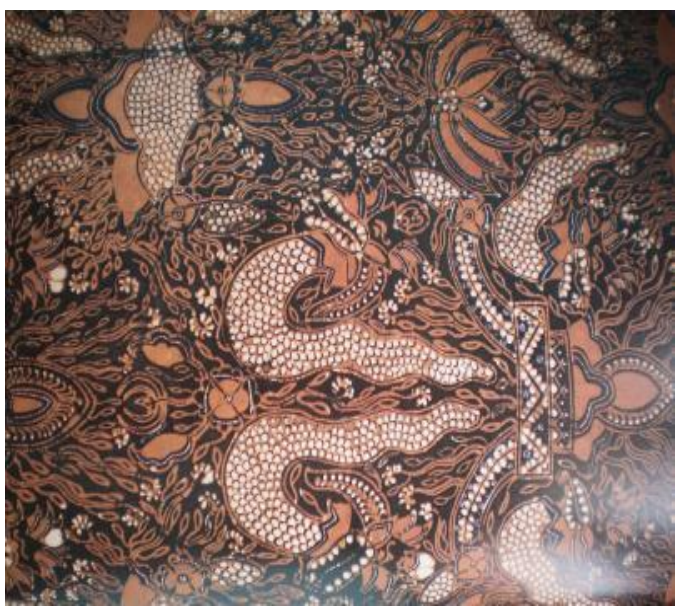

Gbr. 4. Motif batik larangan Semen dengan bentuk naga.

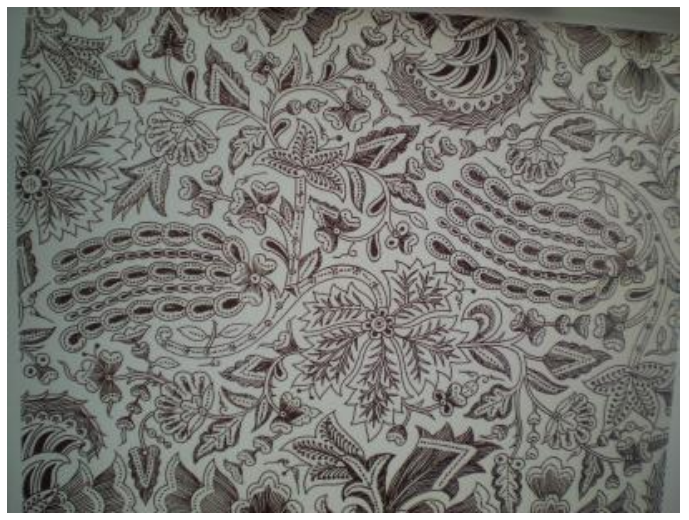

Gbr. 5. Motif batik larangan Semen Kolang Kaling.

Udan liris termasuk pola geometris bermotif lereng. Motif ini bermakna filosofis hujan gerimis atau rintik-rintik yang membawa kesuburan bagi tumbuhan dan ternak. Udan liris terdiri dari lidah api, setengah kawung, banji sawut, mlinjon, tritis, ada-ada dan untu walang. Secara keseluruhan, motif udan liris diartikan sebagai harapan agar si pemakai selamat sejahtera, tabah dan berprakarsa dalam menunaikan tugas dan kewajiban demi kepentingan bangsa (Mari, S. Condronegoro, 2010: 58).

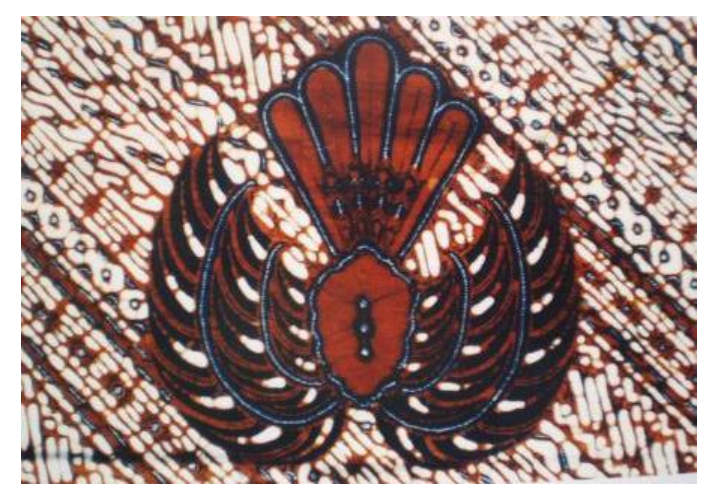

Gbr. 6. Motif batik udan liris menggunakan ceplok gurdha.

Motif sawat menurut mitologi Hindu Jawa diambil dari bentuk sayap burung garuda kendaraan Dewa Wisnu. Gambar Garuda dengan dua sayap 
terkembang bermakna filosofis simbol kekuatan dan kekuasaan. Sawat dapat juga berarti melempar, sebuah kepercayaan mitologi Jawa akan adanya pusaka Dewa Indra yang dapat dilemparkan secepat kilat. Motif sawat mempunyai arti membawa kemakmuran, wibawa dan perlindungan bagi pemakainya.

Motif parang mempunyai makna filosofis sebagai lambang kekuatan, kebesaran, kewibawaan, dan gerak cepat. Motif parang berbentuk lereng atau garisgaris miring dengan ukuran tertentu. Pemakai motif ini diharapkan dapat bergerak cepat dan gesit. Motif parang juga mempunyai pengertian pusat tenaga alam, dalam hal ini raja (Mari, S. Condronegoro, 2010: 51).

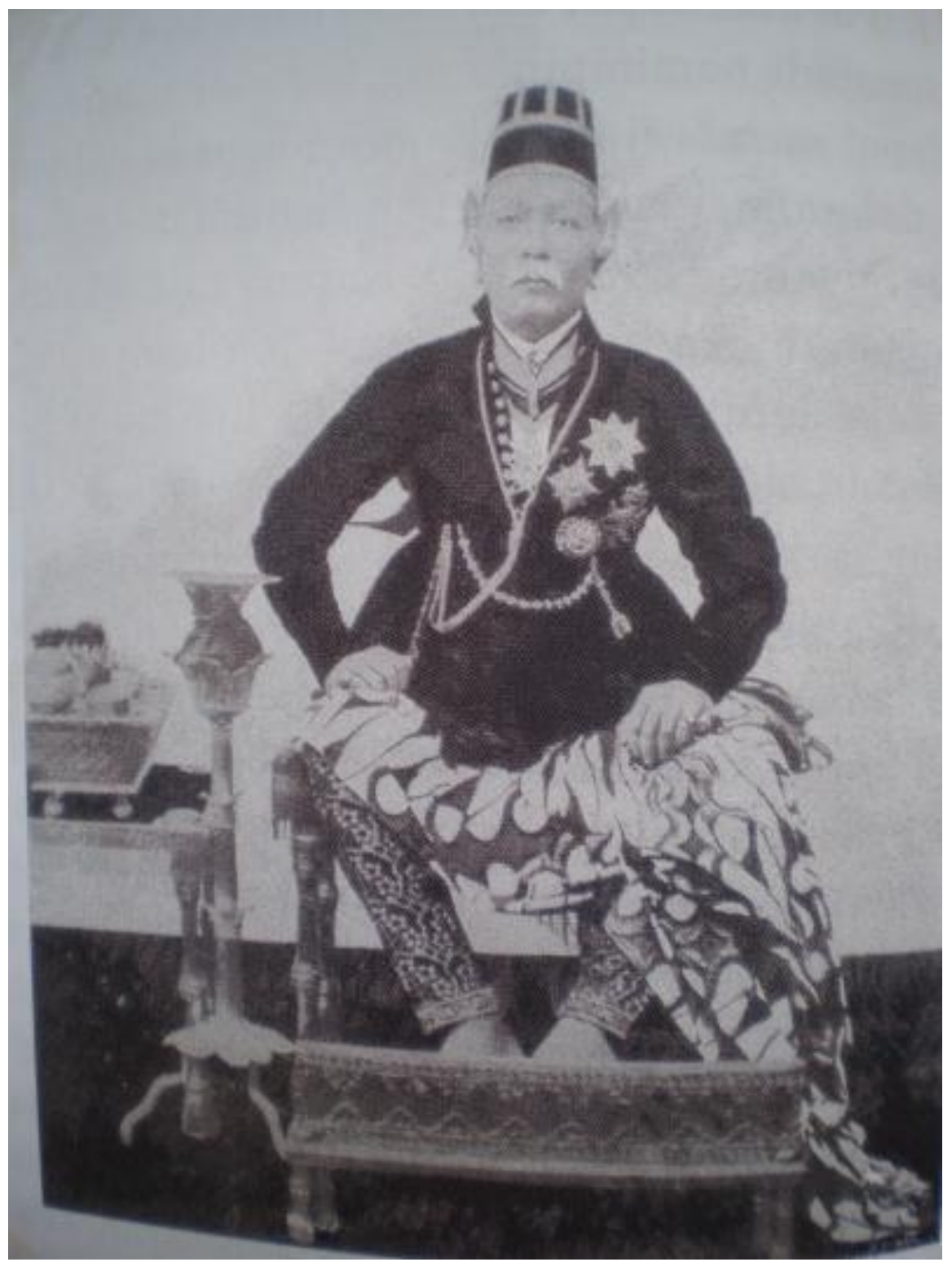

Gbr. 7. Kain parang rusak barong ukuran 10 centimeter dikenakan oleh Sri Sultan HB VII 
Cemukiran merupakan motif yang berbentuk lidah api atau sinar. Api merupakan salah satu unsur kehidupan yang melambangkan keberanian, kesaktian dan ambisi. Pola mirip sinar ini diibaratkan sebagai Syiwa. Syiwa adalah dewa yang menjelma dalam diri raja, sehingga motif ini hanya boleh digunakan oleh raja dan putra mahkota (Mari, S. Condronegoro, 2010: 56-57). Sebagai titisan Dewa Syiwa, Raja Jawa harus mempunyai kewibawaan, keberanian, kesaktian dan ambisi untuk menyejahterakan rakyatnya.

\section{Tinjauan Arkeologis Batik Larangan di Keraton Yogyakarta.}

\footnotetext{
Makna Filosofis batik larangan di Keraton Yogyakarta pada masa pemerintahan Sri Sultan HB VII dapat ditinjau secara arkeologis dari dimensi bentuk, ruang dan waktu. Batik larangan berkaitan dengan wujud yang menunjuk pada dimensi bentuk. Keraton Yogyakarta berkaitan dengan spasial (space) yang menunjuk pada dimensi ruang. Masa pemerintahan Sri Sultan HB VII adalah dimensi waktu karena merujuk pada kapan terjadinya suatu peristiwa (Timbul Haryono, 2010).

Pemakaian batik sebagai motif larangan mempunyai fungsi penggunaannya. Fungsi berkaitan dengan hal-hal yang bersifat teknis (teknofak), struktur sosial atau status sosial (sosiofak) dan prinsip tradisi dalam suatu upacara atau ritual (ideofak) (Timbul Haryono, 2008: 56). Teknofak, sosiofak dan ideofak adalah tiga subsistem dalam fungsi yang saling mempunyai keterkaitan.
}

Batik larangan sebagai teknofak berkaitan dengan teknologi pemakaian alat pembuatan batik. Jenis alat pembuatan batik adalah canting, anglo dan malam atau lilin. Anglo adalah alat yang digunakan untuk perapian kecil. Penggunaan anglo telah digantikan pemakaiannya dengan kompor minyak dan listrik pada masa sekarang. Canting, anglo atau kompor dan malam atau lilin adalah termasuk artefak yang diperlukan masyarakat. Pengertian Artefak adalah benda yang telah dimodifikasi untuk dijadikan alat dengan cara ekstraditif dan aditif, serta mempunyai kegunaan dan berfungsi tetap (Timbul Haryono, 2010).

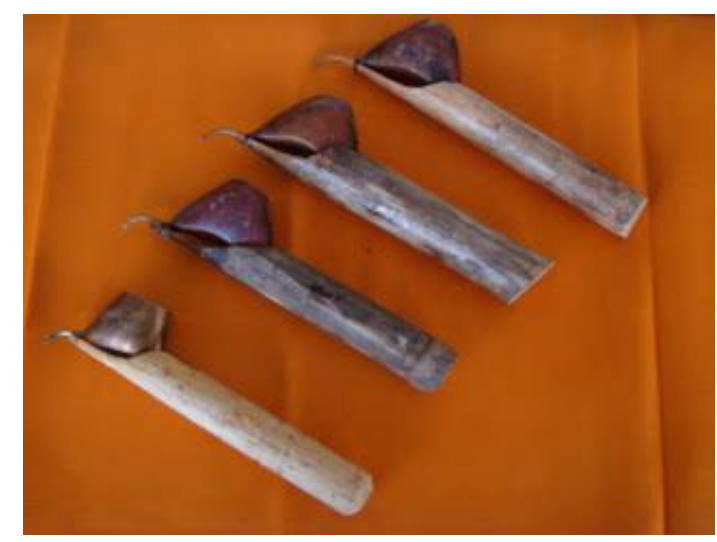

Gbr. 8. Alat pembuatan batik bernama canting

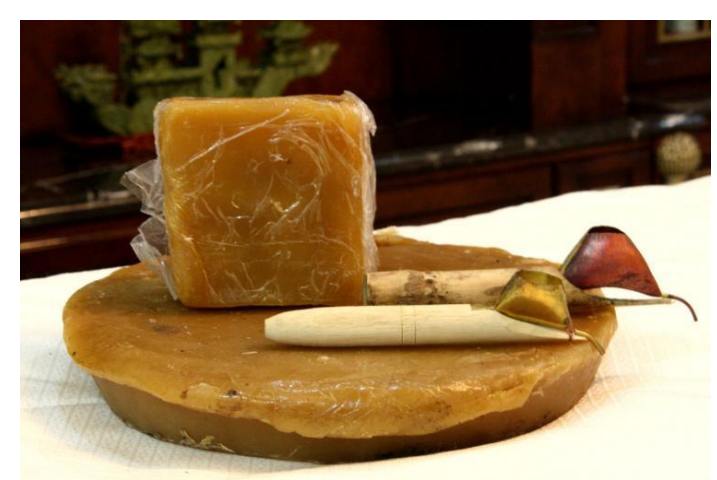

Gbr. 9. Alat pembuatan batik bernama malam atau lilin dan canting 


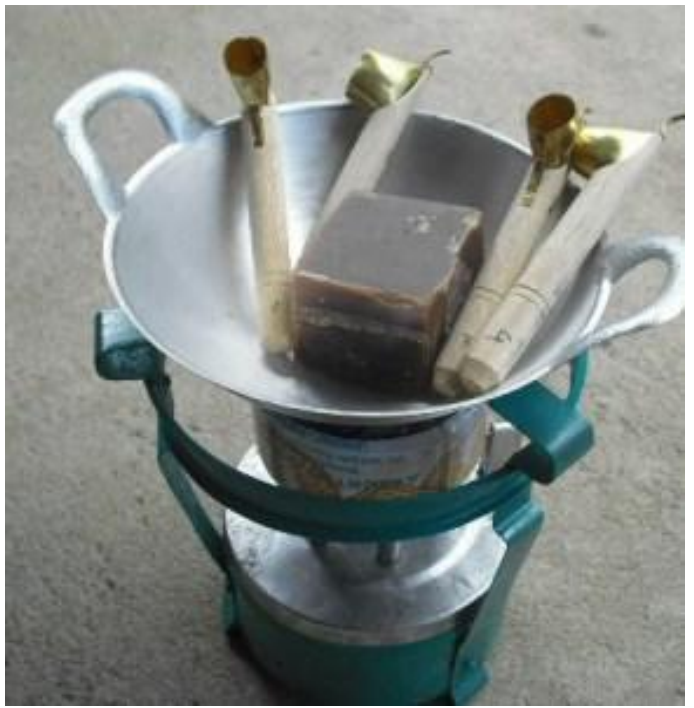

Gbr. 10. Alat yang digunakan dalam membatik yaitu: canting, malam atau lilin, dan kompor minyak.

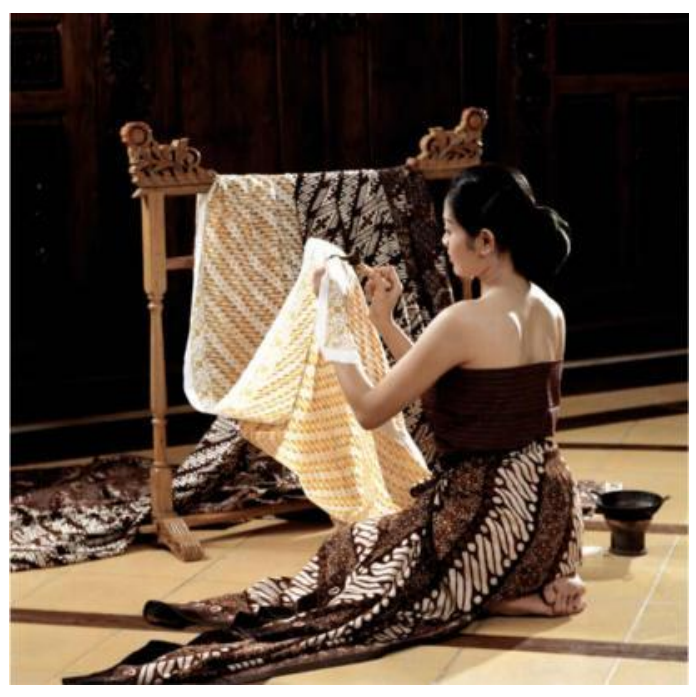

Gbr. 11. Proses membatik.

Penggunaan batik larangan dibatasi pemakaiannya hanya oleh kaum bangsawan keraton. Bahkan khusus motif parang, pemakaiannya diatur dalam Pranatan Dalem Bab jenenge Panganggo Keprabon ing Keraton Nagari Ngayogyakarta. Iwan Tirta menyatakan sebagai berikut.

Dalam tatanan keraton Jawa, kelaskelas penguasa dihubungkan dengan kekuatan gaib tertentu yang sering ditampilkan dalam desain khusus. Mengenakan kain batik harus mengikuti aturan dan melambangkan makna khusus. Sehingga, ada peraturan resmi yang melarang motif-motif batik tertentu digunakan oleh orang banyak.

Batik larangan mempunyai fungsi sosial yang berkenaan dengan status sosial pemakainya. Fungsi ini dinamakan sosiofak dari pemakaian batik larangan.

Membatik telah disebutkan merupakan suatu ibadah bagi lingkungan keraton. Membatik membutuhkan ketelatenan, kedamaian hati dan pikiran untuk menghasilkan motif bermakna filosofis tinggi. Membatik adalah meditasi. Meditasi adalah semacam ritual keseimbangan batin dan penyegaran jiwa (Iwan Tirta, 2009: 178). Fungsi pembuatan batik sebagai meditasi dapat dikaitkan dengan ideofak. Batik larangan berfungsi sebagai alat yang berkenaan dengan prinsip atau ideologi dalam ritual tradisi.

\section{PENUTUP}

Batik larangan adalah batik yang khusus dibuat untuk lingkungan keraton. Pembuatan batik larangan membutuhkan keterampilan dan ketelitian yang tinggi. Hal inilah yang membuat batik larangan sangat eksklusif. Sebagai batik keraton, motif larangan mempunyai makna filosofis. Makna filosofis berhubungan dengan fungsi kegunaannya. Fungsi kegunaan berkaitan dengan subsistem teknofak, sosiofak dan ideofak.

Sehelai kain batik tradisional khususnya motif batik larangan, dipercaya memiliki sukma atau roh yang dititipkan oleh pembuatnya. Kepercayaan ini 
mempunyai keterkaitan dengan ideofak. Jaman dahulu orang membatik untuk berbagai tujuan, misalnya sebagai meditasi atau olah spiritual dan ritual tradisi keraton.

Masa sekarang, fungsi ideofak tersebut telah mengalami transformational process (Timbul Haryono, 2010). Motif batik larangan tidak ekslusif milik bangsawan keraton tetapi telah ditransformasi menjadi milik masyarakat. Motifnya banyak dibuat oleh pengusaha batik dan dipakai oleh semua orang (Wastraprema, 1990: 37). Behaviour process hanya sampai pada pembuatan (make) dan penggunaan (use), bukan lagi mencakup fungsi ideofak.

Walaupun demikian, batik larangan tetaplah harus dilestarikan. Batik larangan merupakan kekayaan lokal bangsa yang mempunyai makna filosofis pembuatannya. Makna filosofis itu bahkan tertuang pada saat canting berisi malam mulai dituliskan di atas selembar kain. Suluk prawan mbathik tumeka mbabar dari sebagian syair Kidung Dhandhang Gula berisi mewakili makna filosofis selembar kain batik, sebagai berikut.

"Suluk mbathik kang pinurwèng singir, lah ta wus bobo bathiken pisan, tenunan wus panigasé. Ywa tinggal polanipun, lawan sira dèn ngati-ati. Kang winadan punapa? Dhasaripun alus, malamira pethak, wus dinuga lancing sedheng sawatawis, acanthing pangrèngrèngan".

"Myang panembokan jegulirèki, wajan ginegèn latu tos ika, bandhul lan gawangane. Apan pepak sadarum, pirantiné wong arsa mbathik. Dhasar alus, utama, tinulis njalinggut. Mangkana umpamanira, yèn dhedhasar wadhag gya tinulis ngremit, karyané yekti ilang".

"Datan pantes yèn tinulis becik, walantenen dèn kongsi kapada, mulih malih mring dhasaré. Yèn awon dhasaripun, babarané nyepeti ati. Mbok prawan dèn prayitna, aja dumèh baut. Sabarang karya bisa, ayu rupa ayu gawé ayu gati, aja kibir jubriwa".

Artinya: "Suluk batik mengawali kidung ini, maka silahkan mulai membatik, morinya telah tersedia. Jangan tinggalkan polanya dan berhati-hatilah. Apa yang masih kurang? Mori yang halus, malam yang putih sudah dicampur sedikit lancing (malam tawon) dan canting reng-rengan, semua sudah siap".

"Canting tembokan dan jegul, wajan yang sudah dipanasi api, bandul dan gawangan yang sudah siap. Membatik mori yang halus, bukankah mengasyikkan? Akan tetapi jika mori kasar tanpa diolah terlebih dahulu, dibatik dengan rumit, hasilnya tidak akan baik".

"Tidak layak dibatik dengan baik, sebaiknya cucilah saja agar kembali seperti semula. Jika bahan dasarnya jelek, hasilnya hanya akan mengecewakan hati. Waspadalah wahai Gadis, jangan karena merasa mampu lalu lupa diri. Setiap berkarya, hendaklah serasi, berpenampilan indah berperilaku elok berhati baik, jangan takabur dan tinggi hati" (Iwan Tirta, 2009: 232-233).

\section{KEPUSTAKAAN}

Anas, Biranul. 1997. Indonesia Indah buku yang ke 8 "Batik". Jakarta: Yayasan Harapan Kita/ BP 3 Taman Mini Indonesia Indah. 
Condronegoro, Mari. 2010. Memahami Busana Adat Keraton Yogyakarta: Warisan Penuh Makna. Yogyakarta: Yayasan Pusaka Nusatama.

Harun, Nasution H. 1992. Ensiklopedi Islam Indonesia. Jakarta: Penerbit Djambatan.

Haryono, Timbul. 2008. Seni Pertunjukkan dan Seni Rupa Dalam Perspektif Arkeologi Seni. Surakarta: ISI Press Solo.

Haryono, Timbul. 2010. Catatan Kuliah Arkeologi Seni pada tanggal 19 Februari 2010. Yogyakarta: Sekolah Pasca Sarjana PSPSR.

Sondari, Koko. 2002. Album Seni Budaya Batik Pesisiran. Jakarta: Proyek Pengembangan Media Kebudayaan.

Suyanto, A. N. 2002. Makna Simbolis Motif - Motif Batik Busana Pengantin Jawa. Yogyakarta: Lembaga Penelitian Institut Seni Indonesia Yogyakarta.

Tirta, Iwan. 1985. Simbolisme Dalam Corak dan Warna Batik. Bonus Majalah Femina No. 12/ XIII.

Tirta, Iwan. 2009. Batik Sebuah Lakon. Jakarta: PT Gaya Favorit Press.

Van Roojen, Pepin. 1996. Batik Design. Netherlands: The Pepin Press BV.
Wastraprema. 1990. Sekaring Jagad Ngayogyakarta Hadiningrat. Yogyakarta: Himpunan Pecinta Kain Batik dan Tenun. 